Institute of $\mathbf{F}_{\text {ood and }} \mathbf{A}_{\text {gricultural }} \mathbf{S}_{\text {ciences }}$

\title{
Water Management District Considerations for Florida Citrus Groves 1
}

\section{Brian Boman and Larry Parsons ${ }^{2}$ \\ Water Management District Functions}

The Florida Water Resources Act of 1972 was enacted following a severe drought in 1971, as part of a package of major environmental and land use bills. (The South Florida and the Southwest Florida Water Management Districts had been created earlier to address flooding and water shortage problems). The act provides for comprehensive water resource management and the division of the state into five Water Management Districts (WMDs, Fig. 1).

The boundaries of the WMDs were established by hydrologic surface water runoff boundaries. The WMDs that govern water in Florida's citrus belt include the Southwest Florida Water Management District (SWFWMD, Fig. 2), the St. Johns River Water Management District (SJRWMD, Fig. 3), and the South Florida Water Management District (SFWMD, Fig. 4).

The WMDs play a very significant role in the regulation of water use and natural resource protection. The WMDs' responsibilities include:

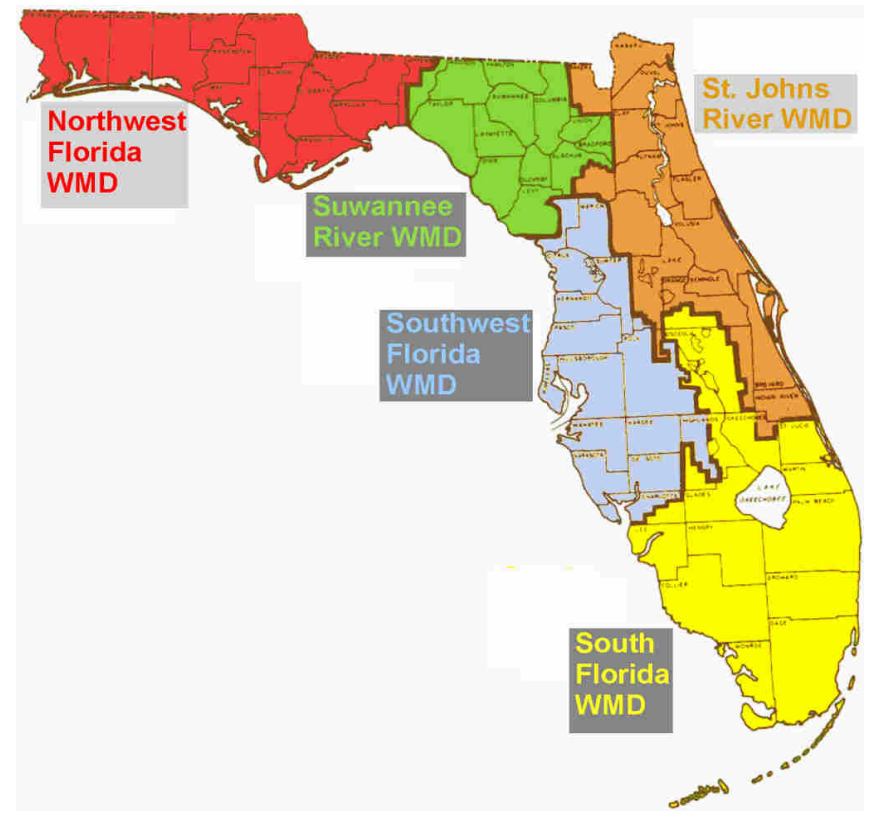

Figure 1. Location map of Florida's five water management districts.

- Management of water and related land resources via promotion of conservation.

- Proper utilization of surface and groundwater resources.

1. This is document No. CH192 and Circular 1422, one of a series of the Agricultural and Biological Engineering Department, Florida Cooperative Extension Service, Institute of Food and Agricultural Sciences, University of Florida. Publication date: September 2002. Please visit the EDIS Web site at http://edis.ifas.ufl.edu for additional publications related to citrus water management. This document can be accessed as http://edis.ifas.ufl.edu/CH192.

2. Brian Boman, Associate Professor, Department of Agricultural and Biological Engineering, Indian River REC-Ft. Pierce; and Larry Parsons, Professor, Horticultural Sciences Department, Citrus REC-Lake Alfred.. University of Florida Cooperative Extension Service, Institute of Food and Agricultural Sciences, Gainesville, FL 32611.

The Institute of Food and Agricultural Sciences is an equal opportunity/affirmative action employer authorized to provide research, educational information and other services only to individuals and institutions that function without regard to race, color, sex, age, handicap, or national origin. For information on obtaining other extension publications, contact your county Cooperative Extension Service office. Florida Cooperative Extension Service/Institute of Food and Agricultural Sciences/University of Florida/Christine Taylor Waddill, Dean. 


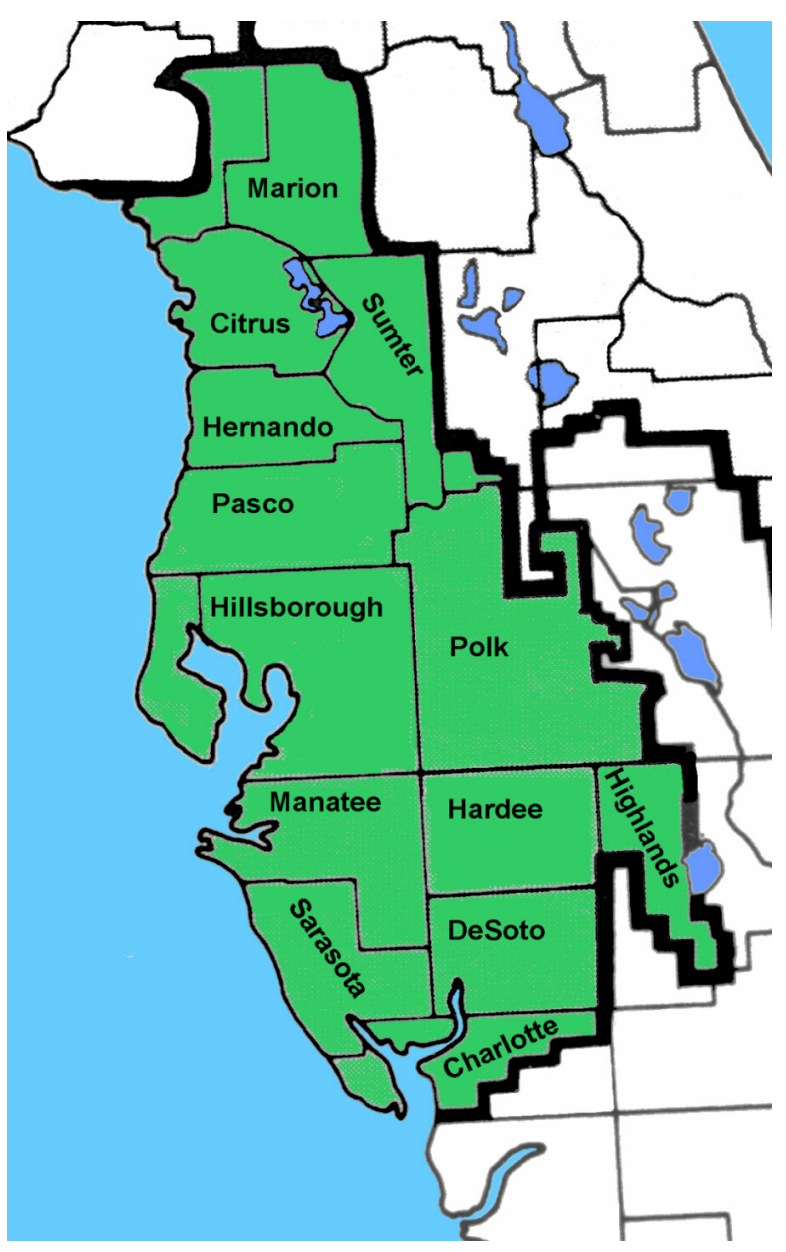

Figure 2. Southwest Florida Water Management District boundaries.

- Regulation of dams, impoundments, reservoirs, and other structures to alter surface water movement.

- Combat damage from floods, soil erosion, and excessive drainage.

- Assisting local governments in developing comprehensive water management plans, particularly by providing data on water resources. To accomplish this, WMDs are authorized to perform various field investigations and to provide works for the beneficial storage of water.

- Maintenance of navigable rivers and harbors and the promotion of the health, safety, and general welfare of the people of the state. Directly attached to this general welfare consideration is the power to implement water shortage emergency plans.

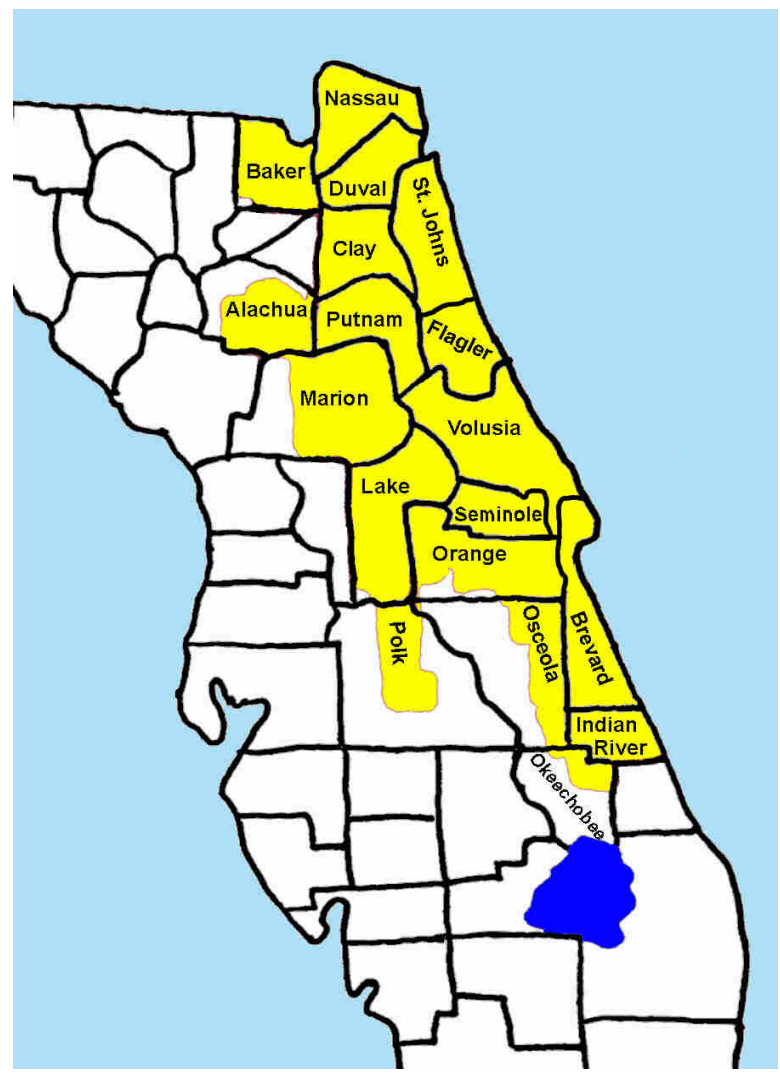

Figure 3. St. Johns Water River Management District boundaries.

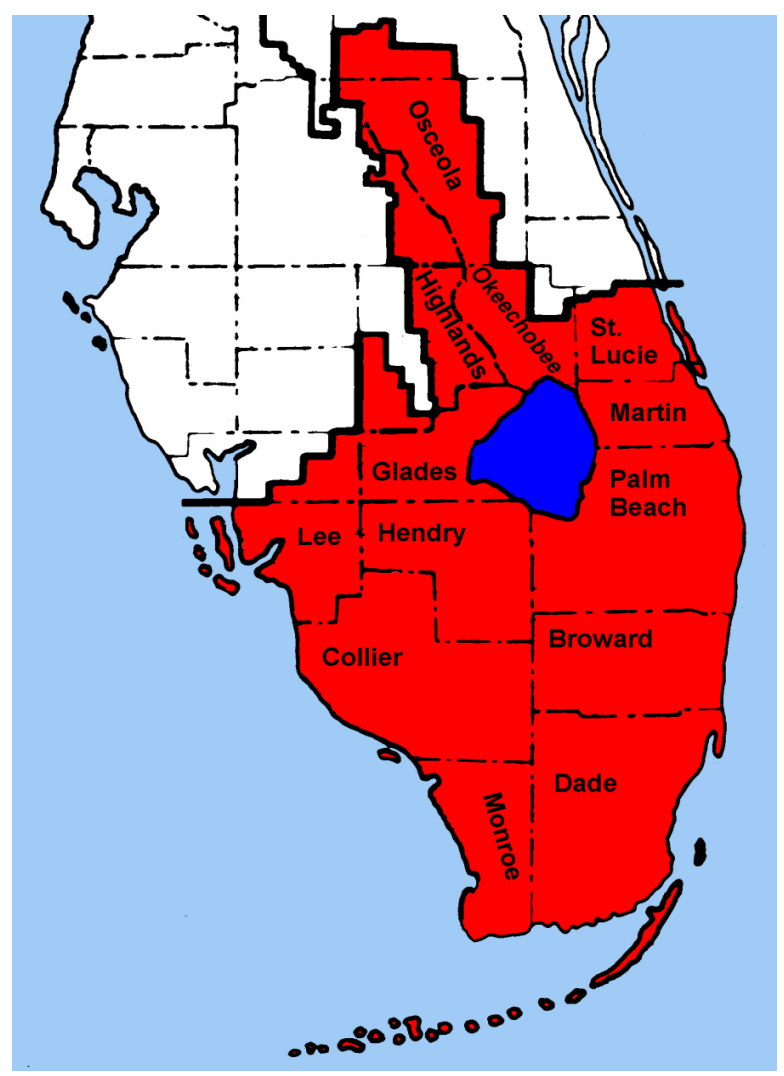

Figure 4. South Florida Water Management District boundaries. 
- Participation in flood control programs, and the reclamation, conservation, and protection of lands from water surplus or deficiencies.

- Maintainance of district water management and use facilities, and determination of levels of water to be maintained in the district bodies of water. To do so, districts may establish minimum flows for their works and water courses, below which further withdrawals would be significantly harmful to the water resources or ecology. This also involves the establishment of minimum water levels for surface water and groundwater.

Each district is autonomous, has ad valorem taxing authority, and is run by a governing board consisting of nine members (except SWFWMD, which has eleven). The members serve four-year terms and are appointed by the governor and confirmed by the state. The governing board sets the policies that will best accomplish the district's mission. Generally, an executive director is responsible for the operation of the district, including the implementation of policies and rules. Typically, each district is divided into departments which handle the various programs, including permitting.

WMD governing board powers include administering the permit programs of Chapter 373, Florida Statutes (Water Resources). Thus, WMDs are responsible for permitting wells, management and storage of surface waters, and issuing consumptive use permits (SFWMD and SJRWMD) or water use permits (SWFWMD). Each WMD has specific criteria detailing the types of activities that require permits, the contents of permit applications, the procedures that surround submission of an application, and areas specifically exempted from permitting requirements. The Governor and Cabinet, sitting as the Land and Water Adjudicatory Commission, have authority to review any order or rule of a WMD.

\section{Permits}

Each of the WMDs has implemented a water use permitting program. In the SFWMD and SJRWMD, the water permits are called Consumptive Use Permits (CUP) and in the SWFWMD, the permits are called Water Use Permits (WUP).

Not all users are required to apply for a permit. When water will be used for domestic consumption by individual users, the user is exempt from needing a permit. In addition, the WMDs have varying thresholds of use, withdrawal capacity, or well size, for which permits may not be required. Other users may qualify for general permits or exemptions, depending on the WMD and circumstances surrounding the intended water use and potential infringement on other permitted water uses.

Applicants proposing new water uses are required to establish that the proposed use :

- Is a reasonable beneficial use,

-Will not interfere with a presently existing legal use of water, and

- Is consistent with the public interest.

Water use permits are granted for fixed periods of time. Duration may not exceed 20 years, except that public facilities may be permitted for up to 50 years if necessary for bonding. In practice, permits have been issued for much shorter durations because the districts have lacked the information needed to commit the resources for longer periods of time. Temporary permits also are authorized. Permits are revocable only for material false statements, willful violation of permit conditions of the Act, and for nonuse of the water supply. Thus, except during times of water shortage or emergency, permittees have certainty of use. The districts generally allow free transfer of permits, provided the use and conditions of withdrawal remain the same.

$\underline{\text { Reasonable Beneficial Use }}$

Reasonable beneficial use is defined as the use of water in such quantity as is necessary for economic and efficient utilization for a purpose and in a manner which is both reasonable and consistent 
with the public interest. It requires efficient economic use of water, a characteristic of beneficial use. In addition, a water user must consider the rights of the general public. Wasteful use of water is not to be permitted under the reasonable-beneficial use standard. Reasonableness and consistency with the public interest also are required, both with regard to the purpose of the use and the manner in which it is carried out.

\section{Harm to Other Users}

Applicants must show that the proposed use will not interfere with any presently existing legal use of water. Existing legal users thus have been granted protected rights for the duration of their permits. Other users cannot gain rights conflicting with existing rights except through the renewal process, at which time a use that better serves the public interest may be permitted instead of the existing use. Often, however, harm to other water users may not become apparent until after the new use has been permitted and begun. In such a situation, state water policy provides for modification of the permit to curtail or abate the adverse impacts.

\section{$\underline{\text { Public Interest }}$}

A CUP/WUP must be consistent with the public interest. Public interest can be defined through rule making by the Florida Department of Environmental Protection (FDEP) and the WMDs. Some of the WMDs have listed criteria for determining the public interest. Generally, however, consistency with the public interest is determined on a case-by-case basis in the permitting process.

\section{$\underline{\text { Planning }}$}

FDEP has been charged with responsibility to develop an integrated, coordinated plan for the use and development of the waters of the state. This responsibility extends to studies of existing water resources, contemplated uses and needs for water, and other subjects such as drainage and floodplain zoning. The product of these efforts is the State Water Use Plan, which is to be combined with state water quality standards and classifications to form the Florida Water Plan. Other FDEP responsibilities include giving consideration to the requirements of public recreation, and to the protection and procreation of fish and wildlife. The WMDs are part of the process in developing these plans.

Additional planning requirements were imposed by the 1982 and 1997 Legislatures. Each WMD was required to develop a groundwater basin resource availability inventory, identifying and analyzing specified basic information regarding groundwater basins and associated recharge areas. Planning to assist rapidly urbanizing areas in meeting water supply needs was mandated, as was the development of water shortage plans. The 1997 Water Resource Development Act required that each District develop a water supply plan to provide water needs for a 1-in-10-year drought.

\section{$\underline{\text { Environmental Considerations }}$}

The effects of consumptive uses on the environment are important considerations in planning, permitting, and preservation of natural resources, fish, and wildlife. The state water use plan may designate desirable uses that are to be given a preference in the granting of CUP/WUPs. Such uses might include preservation of the environment, protection of recharge areas, or recreation. Once established, such a preference must be recognized in permitting. Similarly, certain uses might be declared undesirable because of the nature of the activity or the amount of water required. In such cases, the governing board of a water management district is authorized, but not compelled, to deny a CUP/WUP.

The Water Resources Act mandates the establishment of minimum flows for surface bodies as well as minimum lake and groundwater levels. Commercial navigation, recreational boating, fishing, hunting, swimming, and functioning of the ecosystem are some of the nonconsumptive public purposes that are protected under the minimum flow and level concept in Florida. Minimum flows are to be established at the level at which further withdrawals would be significantly harmful to the water resources or ecology of the area. Minimum levels are the levels of surface or groundwater below which further withdrawals would be significantly harmful to the water resources of the area. 


\section{Water Shortages and Emergencies}

Most WMDs allocate water for CUP/WUPs based on the supply of water required to meet irrigation needs for a 2-in 10-year irrigation requirement. When the supply of water is reduced by drought or overuse, other measures must be implemented to protect the resource and users. The governing board of each water management district is required to adopt a water shortage plan, which includes a system of permit classifications according to source, method of withdrawal, and use. The governing board may implement the water shortage plan in the entire district or a portion of the district when insufficient water is available to meet the requirements of the regular permit system, or when conditions require temporary reduction in use to protect the area's water resources from serious harm. Restrictions may be imposed on all permits, or on specific classes of permits, to protect or restore the water resources.

If the water shortage is an emergency and implementation of the water shortage plan would be inadequate to protect the public, reasonable uses, or the ecosystem, the executive director of the WMD may declare a water emergency. Unlike the water shortage plan, which applies to classes of permits, water emergency orders may be issued to specific users. An order may limit, rotate, apportion, or prohibit use of the water resources and must be complied with immediately.

Each of the water management districts has adopted water shortage plans. These plans classify uses by source within surface water and groundwater categories. Within each category, the source is classified further. For example, withdrawals from the Upper Hawthorn Aquifer are classified separately from withdrawals from the Sandstone Aquifer. Uses are classified within four major groups:

- Domestic.

- Commercial (utility, mining).

- Agricultural.

- Recreation.
A water shortage may be declared for specific sources. Once declared, predetermined restrictions are imposed on each of the use classes. A level of restrictions is imposed depending on the severity of the shortage. Each WMD has its own set of restrictions and criteria. The plan also provides criteria and procedures for declaring a water shortage emergency. Although local authorities are encouraged to adopt and enforce local ordinances to implement the plan, the district is authorized to enforce the plan.

\section{Water Management Permits For Citrus Operations}

Water allocation and resource oversight are accomplished in Florida's citrus producing regions through the regulation programs of the SFWMD in South Florida and the Kissimmee River Basin, SWFWMD in the West Central region, and SJRWMD in the Northeast region. The WMDs issue permits to manage the quantity of surface and groundwater used, and to reduce pollution of water supplies. The WMDs also keep track of how much water is being used throughout the WMDs, and protect associated property and environmental resources from harmful activities. This permitting protects the water needs of the public, existing and future users, as well as the environment.

A permit represents a contract between the land owner or permittee and the WMD. Failing to obtain a permit, if one is required, or to comply with the conditions of a permit, can result in enforcement actions such as fines and other legal action. WMDs issue three main types of permits:

- Water use.

- Well construction.

- Environmental resource or surface water.

Within those main categories are two tiers: general and individual permits. General permits are issued for water quantities or surface water impacts below a specified level, and are approved by the staff of the appropriate WMD. Individual permits typically involve larger quantities or impacts, and require approval of the WMD Governing Board. 
A consumptive water use allows a user to withdraw a specified amount of water from a ground water well or a surface water source. A Well Construction Permit (WCP) is required prior to the drilling of a new well, and the repair or plugging of an existing well. WCPs ensure that wells are constructed by qualified contractors to meet safety, durability and resource protection standards. An Environmental Resource Permit (ERP) must be obtained before beginning any construction activity that would affect wetlands, alter surface water flows, or contribute to water pollution. An ERP is needed to regulate activities such as dredging and filling in wetlands, construction of drainage facilities, stormwater containment and treatment, construction of dams or reservoirs, and other activities affecting state waters. The ERP combines wetland resources and surface water management and storage into a single permit in an effort to streamline the permitting process.

Citrus operations will usually need well construction permits. An Environmental Resource Permit (ERP) might also be needed. A complete ERP application may be needed prior to obtaining a water use permit, and a CUP/WUP may be needed prior to obtaining a well construction permit. In general, the following may be required for citrus operations.

\section{CUP/WUPs are needed to:}

- Irrigate crops with water withdrawn from either a well or surface water facilities.

- Provide water from a well or pond for frost protection.

- Refill irrigation ponds or ditches with water from a well.

- Furnish well water for product spraying or other support activities.

Well construction permits are required to:

- Construct a new well.

- Repair or plug an existing well.

$\underline{\text { Environmental resource permits are needed to: }}$
- Develop grove in an area that currently contains wetlands, or excavate or fill in natural wetlands.

- Construct any facility that will alter surface water flows or runoff, intrude into a floodplain, or contribute to water pollution.

- Construct a dam, canal, impoundment or reservoir.

\section{Wells}

FDEP has delegated most of its authority to regulate water wells to the individual WMDs. Therefore, the appropriate WMD should always be contacted before taking any action involving water wells. The rules are designed to safeguard both the quality of water extracted from the wells and the quality of the aquifer water, both of which could potentially be polluted by intruding wells.

All proposed well sites must be pre-approved by the appropriate WMD. This guards against the possibility that a well will unknowingly be drilled into an area of existing groundwater contamination. The FDEP provides continually updated maps of contaminated sections of the aquifer to the WMDs and pertinent County Health Departments. The WMDs and County Health Departments also prescribe the minimum distances from the contaminated areas in which wells may be constructed.

Each WMD sets permit application fees depending primarily upon the nature of the activity and the size of the well. The fees vary with each WMD. Construction permits are valid for a period of one year. If the construction or repair cannot be finished within one year, the WMDs can either extend the limit, or require a new permit. Most Districts require a CUP/WUP before a well construction permit will be approved.

\section{CUP/WUP}

The various WMDs have exclusive authority to issue Consumptive Use or Water Use Permits, since they are charged with maintaining the state's reserves of usable water at an acceptable level. 
When a grower's required water usage reaches the WMD's specified threshold levels, a CUP or WUP will be required. Threshold levels are determined by the individual WMDs, and it is important to consult the appropriate WMD regarding this threshold. All uses must be permitted. However, there are some uses that may be exempted, including:

- Individual residential consumption.

- Wells for testing or monitoring.

- Private, shallow wells.

- Certain heating and cooling systems.

- Dewatering activities necessary for construction, if they are completed in less than six months.

Exemptions, however, do not absolve growers from complying with intent of the Water Resources Act, and the use of the water supply must be reasonable. Reasonable use may include the purpose of use, suitability of the body of water and social values, degree of harm to the environment, and the practicality of avoiding the harm.

Permits are granted for fixed periods of time. Except for public facilities, they may not exceed 20 years and are usually granted for much shorter periods. When the nature of a proposed use is such that the permit application process may be lengthy, the district may issue a temporary permit. Transfer of permits between activities identical in nature at the same location is usually allowed and conditions of the permit usually remain the same. Any failure to continually observe the terms provided by a permit may result in its revocation.

\section{Environmental Resource Permits}

The governing boards of the WMDs and the FDEP are vested with the authority to require Environmental Resource Permits (ERPs). This authority is delegated almost entirely to the WMDs. Therefore, they should be consulted before any alteration of surface water is undertaken.
The rules governing surface water management include the construction, operation, or alteration of any stormwater management system, dam, impoundment, or reservoir. In effect, the rules apply to virtually every type of artificial or natural structure or construction that can be used to connect to, draw water from, drain water into, or be placed in or across surface water. They include all structures and constructions that can have an effect on surface water including dredging, filling, and activities which create canals, ditches, culverts, impoundments, fill roads, buildings and other impervious surfaces.

However, the statute contains an exception for agricultural operations and citrus growers may alter land tracts without an ERP permit as long as the practices are normal occupational activities whose sole or predominant purpose is not to obstruct or impound surface water. These activities can include site preparation, clearing, fencing or contouring to prevent soil erosion, soil preparation, plowing, planting, or harvesting. The exemption is qualified in that the impoundment or obstruction of surface waters may not be the chief purpose of the alteration. Construction or maintenance performed on dikes, dams or levees in an agricultural closed system will be exempt from ERP permitting requirements. ("Closed system" means a self-contained irrigation system used in farming which does not discharge off-site.) Nonetheless, these works must still comply with generally accepted engineering standards and, where the engineering practice is regulated by the state, this might require proper certification of the project and strict adherence with the original plans. It is always wise to consult with the specific WMD when attempting to determine if a proposed activity is exempt.

Certain WMDs rely on the threshold concept to determine when a permit is required. For example, once a certain quantity of water is impounded or a certain size project is proposed, the WMD will require a permit unless the activity is somehow exempt. Permitting thresholds and exemptions adopted by rule vary among the WMDs. The applicant must show that the planned activity will not be harmful to the water resources, and that the activity will not be inconsistent with the objectives of 
the WMD by showing the project is not against the public interest.

If the planned project significantly degrades the water quality, the applicant can still obtain a permit by showing that the planned activity will be clearly in the public interest. In determining whether a planned activity is not contrary to public interest, there are some criteria that are evaluated:

- Whether the activity will adversely affect the public health and safety of others.

- Whether the activity will adversely affect fish and wildlife conservation.

- Whether the activity will adversely affect navigation or the flow of water.

- Whether the activity will adversely affect fishing or recreational values in the area of the activity.

- Whether the activity is permanent or temporary in nature.

- Whether the activity will adversely affect or will enhance significant historical and archaeological resources.

- Whether the current condition and value of activities occurring in the area will be adversely affected by the planned activity.

If an applicant has trouble meeting the permit criteria, they can still get a permit through mitigation. Mitigation is the creation, maintenance, or restoring of a surface water area in exchange for the degradation of another area. If a project will degrade a surface water body, it may be still possible to get a permit, but that applicant will have to mitigate the damage by creating or restoring another area. The applicant's mitigation plan needs to be approved by the WMD.

After permit approval, following certain best management practices is an excellent way to help ensure continuing compliance with government regulation. Some examples include establishing buffer strips and streamside management zones around a system, maintaining streams and culverts so as not to affect upstream or downstream culverts, and careful construction of access roads.

\section{Permits and Regulations by Other Agencies}

WMD permits and regulation will not eliminate the need to obtain other required authorizations from federal, state and local agencies, or other special jurisdictions. Generally, the WMD staff are willing to discuss this issue with growers and provide information when possible.

Additional information on permits and requirements by various agencies can be found online via the Handbook of Florida Water Regulations at:

http://edis.ifas.ufl.edu/MENU_WQ:WATREG.

A summary of pertinent information can be found in a document titled Environmental Acts and Regulatory Agencies Affecting Citrus Production in Florida at:

http://edis.ifas.ufl.edu/CH161.

Land owners should be especially aware of the provisions of the federal Food Security Act (FSA). Unless federal permitting is approved prior to construction, activities that will affect any wetlands or threatened/endangered wildlife may jeopardize their eligibility for USDA benefits, such as crop insurance, disaster payments, etc. Violations can cause ineligibility on the land owner's entire land holdings.

Prior to any land use changes, land owners should contact the local USDA-NRCS (Natural Resources Conservation Service) office to help delineate the wetlands and provide further assistance as to federal natural resources regulations.

\section{References}

Olexa, M. T. 1991. Handbook of Florida water regulation. Univ. of Florida, IFAS Coop. Ext. Serv. Circ. 1026.

SFWMD. 1996. Guidance for preparing an application for a water use permit. South Florida Water Management District, West Palm Beach, FL. 
SWFWMD. 1996. Tips about getting water management permits for agricultural operations. Southwest Florida Water Management District. Brooksville, FL.

WMD web sites:

SFWMD: http://www.sfwmd.gov/

SJRWMD: http://sjr.state.fl.us/

SWFWMD: http://www.swfwmd.state.fl.us/

\section{Glossary}

CUP: Consumptive Use Permit

ERP: Environmental Resource Permit

FDEP: Florida Department of Environmental Protection

SFWMD: South Florida Water Management District

SJRWMD: Saint Johns River Water

Management District

SWFMD: Southwest Florida Water

Management District

USDA-NRCS: United States Department of Agrculture, Natural Resources Conservation Service

WMD: Water Management District

WUP: Water Use Permit 